\title{
Eficácia do uso de questionários auto aplicáveis no rastreamento de depressão pós- -parto: revisão sistemática da literatura
}

\author{
The efficacy of self-administered questionnaires in the postpartum depression screening: \\ a systematic literature review
}

\section{Acadêmicos: Duana Simakawa, Thais Lumi Matuki Orientadores: Lisandra Stein Bernardes, Marco Aurelio Knipel Galleta, Glaucia Guerra Benute}

Introdução: A depressão pós-parto (DPP) é um transtorno de humor de elevada prevalência e morbidade, com impacto na saúde da mãe e da criança. O rastreamento de DPP parece modificar a evolução da doença, porém, não existe um consenso sobre os métodos e o modo de rastreamento.

Objetivos: Avaliar as ferramentas autoaplicáveis de rastreamento de depressão pós-parto, procurando definir a utilidade de cada instrumento

Métodos: Através da revisão bibliográfica, foram incluídos estudos que avaliaram a eficácia do método através de entrevista psiquiátrica.

Resultados: Foram obtidos, no total, 18 estudos, que contemplaram 8 questionários. O EPDS, PDSS e BDI obtiveram maior acurácia. Os valores de corte, sensibilidade e especificidade variam de acordo com o momento do pós-parto.

Conclusão: Não é possível definir um questionário como superior aos demais para o rastreamento de depressão pós-parto. É possível a utilização de ferramentas específicas, como EPDS e PDSS, e questionários desenvolvidos para depressão comum, como o BDI.

Palavras-chave: Depressão pós-parto; Depressão pós-natal; Rastreamento.

Introduction: Postpartum depression (PPD) is a mood disorder with high prevalence and morbidity that affects the health of mother and child. The PPD screening seems to modify disease progression, but there is no consensus on methods and screening mode.

Objectives: Evaluate the self-administered screening tool for postpartum depression to determine the usefulness of each instrument.

Methods: Through literature review, we included studies that evaluated the effectiveness of the method through psychiatric interview.

Results: There was obtained 18 studies that contemplated 8 questionnaires. The EPDS, PDSS and BDI had higher accuracy. The values of cut off, sensitivity and specificity vary of with the time of postpartum that they are used. Conclusion : It is indicated the use of specific tools, such as EPDS and PDSS, and tools for common depression, such as the BDI

Keywords: Postpartum depression; Postnatal depression; Screening. 